\title{
Language maintenance in an interracial marriage: The case of Indonesian females' language choice in Canada
}

\author{
Rahmawaty Kadir \\ Secondary Education Department, University of Alberta, Edmonton, Alberta, 11210 - 87 Ave. Edmonton, \\ Alberta, Canada T6G 265
}

\begin{tabular}{|c|c|}
\hline $\begin{array}{l}\text { ABSTRACT } \\
\text { This study aims to investigate Indonesian females' langua } \\
\text { the home domain and factors that contribute to their la } \\
\text { seeks to describe the influence of language choice on } \\
\text { amidst multilingual Canada. Semi-structured interviews } \\
\text { collect the data. The participants of this study were } \\
\text { Canadian spouses living in Canadian cities. The study re } \\
\text { language spoken at home in each family despite having } \\
\text { (Indonesian) mothers code-switch between the Indones } \\
\text { discovered that the children are passive speakers of Inde } \\
\text { their mother language. Social context and motivation } \\
\text { participants' language choice. The findings also indicate t } \\
\text { English were taking place in the participants' repertoire. }\end{array}$ & $\begin{array}{l}\text { ice in their interracial family in } \\
\text { choice. Ultimately, the study } \\
\text { ining the Indonesian language } \\
\text { bservations were employed to } \\
\text { female Indonesians with their } \\
\text { that English was chosen as the } \\
\text { donesian mother. Although all } \\
\text { guage and English, the study } \\
\text { some do not even understand } \\
\text { gue factors that influence the } \\
\text { guage shifts from Indonesian to }\end{array}$ \\
\hline Keywords: language choice; language shift; language ma & ce; mixed marriages \\
\hline $\begin{array}{l}\text { First Received: } \\
11 \text { December } 2020 \\
\text { Final Proof Received: } \\
\text { 19 May } 2021 \\
\end{array}$ & $\begin{array}{l}\text { Accepted: } \\
\text { 9 March 2021 } \\
\text { Published: } \\
\text { 31 May 2021 }\end{array}$ \\
\hline $\begin{array}{l}\text { How to cite (in APA style): } \\
\text { Kadir, R. (2021). Language maintenance in an interracial } \\
\text { females' language choice in Canada. Indonesian Jou } \\
\text { 146-156. https://doi.org/10.17509/ijal.v11i1.34589 }\end{array}$ & $\begin{array}{l}\text { The case of Indonesian } \\
\text { Applied Linguistics, 11(1), }\end{array}$ \\
\hline
\end{tabular}

\section{INTRODUCTION}

As the world becomes interconnected and globalized, minority languages are losing their speakers in favor of other languages that dominate world communication. It is estimated that language death progresses at a rate of at least one language in three months (Campbell et al., 2013). The family, being the foundation of language acquisition and language maintenance of minority languages (Canagarajah, 2008; Pauwels, 2016; Schwartz, 2008), can tackle language loss among generations. Many researches have highlighted the family's role in preserving heritage languages (Fishman, 2001; Li, 2006; Igboanusi \& Wolf, 2009; Tse, 2001). Other factors, such as demography (Fishman, 2001; Pendakur, 1990), migration (Romaine, 2017), urbanization (Holmes, 2013), institutional support (Fishman, 2001), and language status (Tawalbeh, 2019), also contribute to language maintenance.
However, according to Pauwels (2005), these contributing factors can only influence "if the family decides to initiate" it (p. 125). Therefore, the family still plays the most crucial role in protecting minority languages from external factors.

Interracial marriages are on the rise in Canada mainly because of globalization and international migration. These practices have brought linguistic concerns because of the family's language maintenance and language shift, which often occurs due to the family's language preferences. Maintaining language is more problematic for an interracial family compared to a family who comes from the same linguistic background. Clyne (2003) showed that language shift is considerably higher among children from mixed marriage families than from marriages within one ethnolinguistic group. Moreover, interaction is often challenging because of linguistic and cultural differences and nationality

\footnotetext{
*Corresponding Author

Email: rahmawat@ualberta.ca
} 
borders that might limit communication. To alleviate the challenge, interracial couples tend to choose a single language. It is believed that a speaker's language choice is influenced by his/her linguistic repertoire (Holmes, 2013). The language choice during interactions can also be prompted by a number of factors, such as the interlocutor, topics, and situations (Fishman, 2013).

\section{Indonesians in Canada}

The arrival of the Indonesian diaspora in Canada began after World War II when the "Indos", referring to Indische Netherlander or a person of mixed Dutch and Asian ancestry such as Indonesians, were repatriated to the Netherlands (Moyer, 2017). Some of these people decided to settle in Canada while others continued their journey to the USA and other European countries. Moreover, the political situations between 1960 and 1970 in Indonesia led people to migrate to Canada. According to their 2016 census, there are 21,390 Indonesians of ethnic origin living in Canada (Statistics Canada, 2018). These numbers include Indonesians who have Canadian spouses. The National Household Survey in 2011 showed that about 360,045 couples, or $4.6 \%$ of all married and common-law couples in Canada, were mixed marriages. Of that number, 305,075 , or $3.9 \%$ of all couples, were composed of one person who was a visible minority ${ }^{\mathrm{i}}$ while the other was not. In comparison, about 54,970 couples, or $0.7 \%$ of all couples, involved two individuals from different visible minority groups.

In terms of language, Canada has officially recognized English and French as the official languages. However, according to Statistics Canada (2018), over 200 languages were reported in the 2011 census as the mother tongue. In the Indonesian-Canadian family, the Indonesian language is considered to be the visible minority language while another language is the dominant language. Therefore, there is a higher chance for children not to learn the minority language. Tandefelt (1992) stated that, "in a mixed family, the minority language is clearly used to a more limited extent in the generation of children than in that of the parent who could have given this language as an inheritance" (p. 155).

Statistics Canada (2018) revealed that there is an increasing number of Canadians reported to speak a mother tongue, or a language other than English or French, at home. As a multilingual country, two other language groups are spoken across Canada: Aboriginal languages and Immigrant languages. Aboriginal languages are languages traditionally spoken by the Aboriginal people of Canada, such as First Nations (North American Indians), Métis and Inuit, etc. In contrast, the Immigrant languages refer to languages that exist primarily because of migration following the
English and French establishment. These languages are considered to be the home language. Statistics Canada (2018) also reported over 215 home languages in the 2016 census.

Indonesia is a country located in Southeast Asia, an archipelago with over 17,000 islands and about 1,000 ethnic groups. In addition to the Indonesian language, which is the country's sole official and national language, the Ethnologue listed the number of individual languages spoken in Indonesia as 722 . From this total, 710 are living languages with various degrees of language vitality, while 12 have already vanished (Eberhard et al., 2020). It is therefore evident that bilingualism and multilingualism are common in both countries of Canada and Indonesia. While Canada officially recognizes two languages, English and French, Indonesia acknowledges the Indonesian language as the official language.

\section{Language maintenance and language shift}

The study of language maintenance and language shift cannot be separated from each other. They both focus on the relationship between change or stability in habitual language use and ongoing psychological, social, and cultural processes, mainly when communities with different languages are in contact with each other (Fishman, 1965; Pauwels, 2016). Fishman (1965) stated that language shift and the other side of the coin, language maintenance, are a long-term process of combined results of language choice. Language maintenance refers to a condition when a speaker or a group of speech communities continues using their language in some or all aspects of their life despite the pressure and competition from the more powerful, dominant language (Pauwels, 2016). In language maintenance, a speech community keeps using the language in one life domain or more, although language contact occurs with the mainstream language. An example of language maintenance can be seen when a language speaker moves to another linguistic territory, but this individual keep maintaining his/her language. Pauwels (2016) further explained that language maintenance can be considered healthy when the migrated group can provide their needs for themselves and have minimal contact with the broader community for their existence, even though the dominant language will indeed infiltrate this minority language group for some functions or in specific situations. Pauwels (2016) likewise introduced several major factors in identifying a condition of language maintenance: 1) the period of continued use since the first language contact; 2) the extent to which it is the exclusive language in any given context; and (3) the domains or spheres of usage in which the minority language continues to be used either exclusively or in conjunction with another language (p. 21). 
On the contrary, language shift occurs when a speech community gives up their language in favor of another language (Pauwels, 2016), at least in one language domain (Clyne, 2003) such as home, school, religious and government services. In a multilingual society, language maintenance can be achieved by motivating children to learn the language and educating them about the language and culture. In this sense, Baker (2000) suggested regular use of a language in the family, friends, and community strengthen language maintenance. Clyne (2003) also suggested having a positive attitude is required in language maintenance.

Fishman (1991; 2001) and Skutnabb-Kangas $(1981 ; 2013)$ revealed that a community's motives to maintain their language include a sense of group identity and group membership. Fishman (1991) viewed a strong sense of ethnic identity as a central factor contributing to language maintenance. As long as the language was considered an essential part of that identity, the community will preserve their language. It was emphasized that language maintenance must involve the intergenerational transmission of the language. If intergenerational transmission of a language stopped, it can be said that the speakers have shifted to another language.

\section{Language choice in multilingual communities}

In 1965, Fishman asked an intriguing question, "Who speaks what language to whom and when?" as an analysis for the study of sociolinguistics in bilingualism. This quote has become a foundation for the study of language choice. Fishman (1965) defined language choice as what language a speaker chooses to use in a particular situation in bilingual or multilingual communities. A multilingual language user has several language choices to make contact with other people. Fishman (2013) described that within multilingual groups, language choice is far from random: "Proper usage dictates that only one of the theoretically co-available languages or varieties will be chosen by particular classes of interlocutors on specific kinds of occasions to discuss particular topics" (p. 437). This implies that the choice depends mostly on the interlocutor of a conversation, and language contexts, including where and when the conversation takes place and the topic of the conversation.

In the same vein, Romaine (2017) concluded that having a language choice indicates that multilingual people do not always consider the language they know as adequate for all speech situations. In addition to the speech situation, Apfelbaum \& Meyer (2010) added that multilingual people may choose to communicate in a specific language to compensate for the lack of proficiency in another language. Therefore, language proficiency also plays a significant role in determining language choice.
Romaine (2017) said that one of the motivating factors for language choice is the "act of identity" or choosing the groups with whom they want to identify (p. 518). To perform the "acts of identity" when selecting to use one language over another language, multilingual speakers base their choice on their intention to categorize or identify themselves with a particular group, such as an ethnic group, national group, peer group, or ideological group. In interracial marriages, choosing a language is far more complicated. To avoid conflict in communication, the couples might have to choose a common language. However, whose language is supposed to be the language of communication? Based on the researcher's experience as someone involved in an interracial marriage, English has been chosen as the language of communication simply because it is the language where both of the couple have a similar proficiency. Rosenblatt (2009) noted that a couple's chosen language was more likely to be the language of the partner who has more power within the relationship. According to Piller (2009), it also might depend on the place of residency. This choice may be an ongoing negotiation instead of a one-time decision. Ultimately, speaking a common language is vital for their daily communication as a couple and family.

Language choice in interracial marriages contributes to language shift or language maintenance (Baker, 2000; Clyne, 2003; Holmes, 2013; Pendakur, 1990; Tandefelt, 1992). Pendakur (1990) noted that mixed marriages are the most crucial factor that causes French-English language shift among French and English communities along Québec and Ontario's border. In another study, Clyne (2003) confirmed that language shift in Australian immigrant groups is considerably higher among children from mixed marriage families than from marriages within one ethnolinguistic group. If one parent speaks a minority language and another speaks the dominant language, there is a higher chance that one parent will not pass the minority language to the children. In this study, Indonesia language is considered to be a minority language in Canada while English as the majority language. This is not surprising that mixed marriages became one of the significant factors that contribute to language shift inside the family (Cheng, 2003; Igboanusi \& Wolf, 2009; Romaine, 2017). Several studies have emphasized the role of the family in preserving minority languages (Berardi-Wiltshire, 2016; Clyne \& Kipp, 1997; Smith-Christmas, 2015; Okita, 2001), as well as the impact of mixed marriages on language shift (Baker, 2000; Clyne, 2003; Holmes, 2013). However, factors that specifically address the language choice in mixed marriages who are living in countries where the dominant language is English, and the impact of the language choice particularly for the female spouse 
who speak a minority language, are typically understudied.

The present study investigates the language choice in the homes of Indonesian females who have Canadian spouses as well as factors that contribute to their language choice. This report highlights the implications of language choice on Indonesian heritage language in Canada. Specifically, this study intends to answer the following research questions: (1) Which language(s) are used among Indonesian mixed marriage families in the home domain? (2) What are the factors that contribute to language choice of the female Indonesians?

\section{METHOD}

This study used a qualitative case study method (Cresswell, 2018) to investigate Indonesian females' language choices and factors contributed to their language choice at home. A purposive sampling technique was used to determine the number of the subjects. Purposive sampling is a technique widely used in qualitative research as the most useful and effective sampling strategy for the identification and selection of participants in limited resources (Patton, 2015). This sampling technique does not provide equal opportunities for each element or population member to be selected as a sample (Cresswell \& Plano Clark, 2011). This involves identifying and selecting individuals or groups of individuals that are incredibly knowledgeable about or experienced with a phenomenon of interest (Cresswell \& Plano Clark, 2011).

This study focuses on the language choice of three Indonesian females involved in mixed marriages and living in Canada. The invitation to participate in the research was sent via email to the Indonesian community mailing list in Canada. The request required participants who have a Canadian spouse, currently live in Canada, have been married for at least three years, and with children. About two weeks after the invitation was sent, five people responded and were interested to take part in the study. However, two of the participants withdrew from the study for personal reasons. Therefore, the researcher ended up with a total of three female Indonesians. The small number of participants was perceived as the limitation of this study. However, the researcher interviewed all the participants who were willing to be part of the study.

All three participants have been married for over ten years, and they have either two or three children. They all hold at least a bachelor's degree from the universities in Indonesia. They moved to Canada shortly after getting married to be with their husbands, who are Canadian citizens. It is important to note that although it was not the researcher's intention, all the participants' spouses were white Canadians born and raised in Canada. All the children of the participants were likewise born and raised in Canada. Table 1 shows detailed information about the background of all the participants.

Table 1

Background Information of Participants

\begin{tabular}{llll}
\hline \multirow{2}{*}{ Background Information } & \multicolumn{3}{c}{ Participants } \\
\cline { 2 - 4 } & Mrs. A & Mrs. B & Mrs. C \\
\hline Years of marriage & 12 years & 10 years & 18 years \\
Participant's native language & Javanese* Indonesian & Indonesian & Batak* Indonesian \\
Spouse's native language & English & English & English \\
Participant's level of education & Bachelor's degree & Bachelor's Degree & College Diploma \\
Spouse's level of education & Bachelor's degree & Bachelor's Degree & High school diploma \\
Children's age & 12 (daughter) & 9 (son) & 16 (son) \\
& 5 (daughter) & 8 (son) & 13 (daughter) \\
& & 2 (son) & 10 (son) \\
\hline
\end{tabular}

Note: *Indonesia's indigenous language: Javanese is spoken on Java island, and Batak is spoken in North Sumatra

Semi-structured interviews were held in each participant's house for about 45-60 minutes. The interviews were audio-recorded with the permission of the participants. A week later, the researcher arranged to do an observation during family time. The participants agreed and invited the researcher for observation for about three hours, during which the families of the participants were preparing dinner and then had their dinner together.

To analyze the data, the interviews were transcribed, and field observation notes were collected. Thematic analysis was applied, following Cresswell \& Cresswell's (2018) recommendations, to classify categories and to list themes that may arise from the data. After the interview data were transcribed, interviewee responses were coded as participants Mrs. A, Mrs. B, and Mrs. C, according to their order of interview. Participants' answers to the interview questions and notes from the observations were read and re-read carefully by the researcher to develop familiarity. The researcher then coded the data into possible themes and assembled all related data to each possible theme to ensure the coding's quality. Lastly, the researcher identified emerging themes refined from the potential themes and the overall readings. 


\section{RESULTS}

\section{Language choice in mixed marriage families}

The interviews revealed that all three Indonesian female participants speak more than one language: local (indigenous) Indonesian language, Indonesian, and English. When asking about their first language, two participants acknowledged local Indonesian languages such as Javanese and Batak were considered to be the first language. The Indonesian language was their second language, while English was their third language. One participant who was born and lived in Jakarta, the capital city of Indonesia, does not speak any local Indonesian language. Therefore, she considered Indonesian to be her first language and English as her second language. Regarding their language proficiency, all of the participants deemed to be proficient English speakers even though this language has only been learned intensively after their arrival in Canada.

Responding to the interview question "what language do you use at home situations with your husband, children, relatives, and friends?", all the participants declared that English dominates the language used at home. Communication with the spouse at home was conducted only in English. While conversing with their children, the participants often use English too, but sometimes they code-switch between English and Indonesian. Following is an excerpt of interview with Mrs A. who speaks Javanese, Indonesian and English.

"I use English only when talking to my husband because he does not speak Indonesian. As for my mother-in-law, she often stays in her room, so my communication with her is limited and it is always in English. For my kids, I used the Indonesian language when they were babies. But as they grow up, they prefer to use only English." (Mrs. A)

"English is dominant in my household. My husband only speaks English and understands only some words in Indonesian. So, I do not force him. Also, everyone speaks English here. As for my sons, I use English and Indonesian... but their answer is always in English.” (Mrs. B)

Mrs. C likewise acknowledges that she only uses English when speaking with her husband and children. She further disclosed that she used to talk in Indonesian with her children, but they always responded to her in English. Her first language, Batak, is what she speaks when she calls her family back home and talks to her Indonesian friends.

"When I first came to Canada, I spoke only broken English. My husband taught me English. Then it (English) became our main language for communication... everywhere is English... My children are big now. I used to speak Indonesian with them, but I got tired because somehow... they do not understand what I ask or tell them to do. But they know some Indonesian words." (Mrs. C)

It is evident from the interviews that English was the primary language of the participants for communication at home. The main reason for this choice is they want to accommodate their partner, who does not speak their language. Moreover, their place of residency likewise influences their language choice.

The participants did try to introduce Indonesian to their children by code-switching between English and Indonesian through their conversations when their children were younger. However, the children's responses were always in English. The observations made in this study confirmed that the children were not able to produce even simple phrases, more so a complete sentence, in Indonesian during their conversations.

It was also found that Javanese and Batak, the first language of two participants, were rarely used with the children. As a result, none of their children were familiar with their mother's first language. This is not surprising because the two participants were more concerned about their children learning Indonesian rather than their first language.

"...Indonesian are spoken by all Indonesians rather than my mother tongue (Javanese). Everywhere we go in Indonesia, people speak Indonesian. So, it will be better for them to learn it." (Mrs. A)

"...because it (Indonesian) is the national language, every Indonesian speaks Indonesian including my family." (Mrs. C)

Second after English, the Indonesian language has been perceived to attract more prestige and benefits for the children, compared to the local Indonesian language from their mother's repertoire.

Aside from the spouse and children, English was also the main language used for communication with colleagues outside the home. Outdoors, the participants revealed that they try not to speak in Indonesian to avoid judgment from other people. But when they receive Indonesian guests, family or friends at home, or when they attend Indonesian gatherings, they also switch between Indonesian and English.

"If I go to the playground with my kids, I think I use English...because sometimes people look at us if I use Indonesian. If around the Indonesians (in a gathering), I try to speak Indonesian” (Mrs. A)

"It depends; sometimes Indonesian but often both...I don't want people to look down on us just because I do not speak English.” (Mrs. B)

"Outside home, if we go to the mall or even doing groceries with kids, I use English. I feel if I use Indonesian outside (the home), my family will become the center of attention." (Mrs. C)

Factors influencing language choice in mixed marriage families

Responding to the question "what are some reasons of choosing different language?", the analysis showed that several factors such as the addressee, 
context or situation, topic, motivation, and the children's own language preferences have influenced the participants' language choice.

\section{Addressee}

This is the first factor that determines language choice. Each female participant stated that they chose a language depending on whom they were speaking to. Because their spouse does not speak nor understand Indonesian, the participants had to speak in English when communicating at home. They acknowledged that there was an intention to accommodate the husband's linguistic knowledge by speaking only in English. One participant admitted even where there were Indonesian guesses at home, when her husband was around, she would switch entirely to English. All participants seemed to believe that to reduce misunderstanding and conflicts one language need to be used.

Two participants, Mrs. A and Mrs. B, used some Indonesian words when communicating with the children, as verified through the observations done for this study. Mrs. A often switched to Indonesian when asking or when giving instructions to the children. However, she would repeat the sentences in English because she was worried the children might not have understood what she said. When her husband came home from work, she switched entirely to English language. As for Mrs. B's household, she revealed that because her husband does not speak Indonesian, she tries to accommodate him by speaking only in English. This was confirmed during a visit to the family house. Mrs. B spoke only in English when communicating with her husband. But some Indonesian words were heard when she talked to her eldest son. In contrast, one participant does not use any Indonesian at all. Despite having Batak as her first language and Indonesian as her second language, Mrs. $\mathrm{C}$ does not use any of these at home. Conversations held during family time with her husband and children were exclusively in English.

In each family, all the children speak English fluently while they have very little to no understanding of Indonesian. Considering that all the children were born and grew up in Canada, they have very little chance to immerse themselves in the Indonesian language except through their mothers.

\section{Situation, social context and length of living overseas}

In mixed marriage families, social situations influence the language to be used. In all the participants' households, different situations initiate a different language choice. When having Indonesian friends as guests, the participants chose to have conversations in Indonesian. Sometimes when their guests were from the same ethnic groups, such as Javanese or Bataknese, they switched to both Indonesian and their local languages. However, all participants confirmed that when their husbands join the conversation or were at home, they prefer to speak in English even in the presence of their Indonesian guests.

As English is the official language in Canada and the primary language used in the community where they live, it is also the language used by the participants outside their home, at their workplace, children's schools, and even while conversing with a neighbor next door. This extensive use of English is the reason the participants perceived it would be beneficial for their children to be proficient in this language.

"I use English at home because people around us use English. I want my children to have a good education in English." (Mrs. C)

During visits of their family to Indonesia, the participants claimed to speak mostly in Indonesian and their local languages (Javanese or Batak). Meanwhile, the children were faced with the reality that not all Indonesians are able to speak and understand English. Thus, they had to force themselves to use Indonesian words. However, each visit would last for a maximum of only four weeks for every two to three years. Therefore, the impact of learning the Indonesian language to the children is limited. According to the participants, their children have only a short time to learn Indonesian, and with lack of involvement with the Indonesian community where they live, it became more difficult for them to learn and master the Indonesian language. Some of their teenage children can understand Indonesian but are only passive speakers.

Another factor influencing language choice and maintenance is the length of residency. Mrs. C, who has been living in Canada for 18 years, said that she often needs to pause and think to recover her vocabulary for certain words in Indonesian and Batak. Similarly, Mrs. A, who has been living in Canada for 12 years, has had the same experience trying to recall specific words in her native language, Javanese. In contrast, Mrs. B, who has been living in Canada for 10 years, has asserted that she had not experienced Indonesian language loss due to her active involvement with the Indonesian community.

\section{Topic}

A topic can be a regulator of language choice in multilingual settings. Changing topics may trigger a switch to use another language. This study found that, despite using English as the main language of communication at home, the participants switched to Indonesian when talking about specific topics, such as the name of food and hygiene: "so, tonight kita dinner with Rendang pedas", "Joe, mau chicken barbeque”, "Spaghetti saus merah biasanya paling favorite", "tolong lap... lap meja". Whenever specific words for particular things in Indonesian were forgotten, such as names of vegetables or 
fruits, the participants would immediately switch back to English. For instance, Mrs. A asked her son to get her some spinach on the table, "tolong ambil spinach".

There was a desire to pass on the Indonesian language from the participants to their children, especially because the children cannot communicate properly with their family in Indonesia. Still, there was an obvious shift or erosion in the quality of the participants' mother tongue. Both the interviews and observations revealed that the participants sometimes forget the names of specific items in the Indonesian language. For example, when asking her son to get bananas from the table, one participant chose the English word instead of Indonesian. At other times, the participant paused to get the Indonesian term right for a specific vegetable.

Given that the observations were conducted during the family preparations for dinner, the researcher was only able to take note of words related to this topic. More observations are needed to determine what other specific topics might trigger code switch to the Indonesian language in the mixed marriage family.

\section{Intrinsic and extrinsic motivation}

The choice to make English the primary language at home was made not only to compensate for the husband who does not speak Indonesian, but rather due to the participants' intrinsic motivation as well. The experience of having difficulty getting employment due to a low level of English proficiency has led to decreased confidence. One participant revealed that it had been hard for her to find a job during her first year of arrival in Canada. She had to spend two years improving her English skills before she finally got hired. This kind of motivation also prompted the participants to use English more often when talking with their children, in hopes of reaping more benefits with being fluent in this language. Additionally, as a minority language, Indonesian has lower prestige. Hence, the participants feel uncomfortable using it outside the home, thinking it could lead to some amount of discrimination.

In addition to intrinsic motivation, extrinsic factors also influence language choice. Mrs. B chose to use English when communicating with her children because of advice from professional people, including school teachers and speech therapists for her children's speech delay. Another significant motivation is pressure to use English to do daily routines, such as grocery shopping, paying bills, school meetings, etc. Without proper use of English, it would not be easy to complete daily tasks as a citizen in an English-speaking country.

Although English has been regarded as the most spoken language at home, the function of the Indonesian language as the national language in Indonesia still influences the participants to try and consider teaching their children the Indonesian language. They admitted the advantages of Indonesian and Indonesian local languages in the lives of their children, most especially that of communicating properly with their family in Indonesia. However, in spite of recognizing this benefit, little to no effort was still being made to improve on the children's Indonesian language aside from code-switching at home.

\section{Language proficiency and skills of the parents}

Through self-rating language proficiency interviews, two participants stated that they have high intermediate proficiency in English, while one participant considered herself a highly proficient speaker.

"I can understand almost all things in English. I can speak with my husband and understand him perfectly. But I'm not sure about my English writing because I found it a bit difficult to deal with my children's school assignment. I guess I am a high intermediate." (Mrs. A)

"I speak English well and my English improve(s) day by day. At the beginning, it was difficult. But now, I think I can understand and I can hold a conversation better with my children's teachers." (Mrs. B)

"I can understand native English speakers even when they are speaking quickly. Nowadays, I can talk fluently about any topic. I think I have only little language errors and my pronunciation is very good." (Mrs. C)

Two participants who consider English as their third language (local languages, Javanese and Batak, first and Indonesian second), both agreed that they are now proficient English speakers and have experienced language shift from Indonesian to English. In contrast, one participant who considers English as her second language next to Indonesian, thought that she has a balanced proficiency in both languages.

\section{Children's own language preference}

The participants mentioned that they were able to use both Indonesian and English back when their children were in their early years of life. Once the children entered school, however, and had peers who speak in English, the children started preferring to speak only in English at home. Although their mothers still code-switch at times, the children no longer reproduced the Indonesian words. The participants, likewise, did not have the persistence and commitment to make an effort to ask the children to repeat their responses in Indonesian those that they have spoken in English.

\section{DISCUSSION}

Multilingual or bilingual speakers in every language community have a range of language choices available, which they may switch to and from at any 
time, depending on the given situation. $\mathrm{Bi}$ - and multilinguals often choose their language varieties and switch between different languages (Grosjean, 1982; Wardhaugh, 2010). In mixed marriage families, language choice is often challenging because there are two individuals who have different languages and cultures involved.

This study revealed that the language choice among Indonesian mixed marriage families is dominated by English. It was found that speakers modify their speech to encourage further interaction and decrease the participants perceived disagreements in the interaction. In the same manner, since both parties are bilinguals, they may choose the language in which they both are most proficient and a language in which one interlocutor has greater fluency (Gilles et al., 1977; Wei, 2000). Additionally, given that the participants were all living in Canada, where the primary language for communication is English, the neighborhood, school, and place of residency were also found to influence the language choice. This validates Piller's (2009) conclusion that the place of residency impacts language choice among mixed marriage couples.

Certain topics can only be discussed in a certain language for intimacy and familiarity. Female Indonesians use English when speaking with their husband to maintain their good relationship, but use Indonesian when talking about specific topics, such as food and giving instructions to their children. Indonesian language is also used when talking with family and friends. An exception is when an Indonesian friend can speak in English, and the conversation was initiated in English. This agrees with Giles et al. (1977), who claimed that speakers converse according to their interlocutor's style of speech, by adjusting their speech to suit the needs of the person being spoken to.

While discussing food and ingredients, the speakers may have chosen to speak in Indonesian because the participants were more familiar with that language. They tend to use a particular style when discussing a certain topic based on the assumption that discussing a specific matter might be better with a particular language. As mentioned by Fishman (2001), "certain topics are somehow handled better in one language than in another, in particular, in multilingual contexts" (p. 92). The speaker may think that a certain language has a lack of terminology and relevant vocabulary for discussing a certain topic. More observations and studies are needed to find out other topics that might initiate a specific language choice from the participants' repertoire. Fishman $(1965 ; 2001)$ uses the term situation to describe a larger variety of aspects, such as the settings, topics, functions, and styles of a speaker. The concept of situation concentrates on the aspect of styles that give a clue about the degree of intimacy and formality of a conversation. The style can also display information about the status of interlocutors as well as demonstrate power and solidarity. It means certain styles in different languages may articulate the relationships between the speakers in terms of their intimacy, formality, and equality (Fishman, 1965). Similarly, the choice may be triggered by the contexts and available choices in which the multilingual speakers find themselves (Romaine, 2017).

With regards to language proficiency, it is difficult for the participants to maintain the same level of proficiency in all languages they speak. The participants have acknowledged that they are fluent speakers of English. However, they also admitted that they have shifted and often forgot specific words in their native language. Romaine (2017) stated that multilingual individuals rarely have equal fluency in all of the languages they know, since different languages are used for various functions. It is clear that multilinguals use their languages for different purposes, in different domains, to accomplish different things. Their fluency level in each language depends on their needs for that language (Grosjean, 1982; Romaine, 2017). Apfelbaum \& Meyer (2010) likewise concluded that multilingual people may choose to communicate in a specific language to compensate for their lack of proficiency in another language. Since bilingual speakers are not always equally proficient in both languages, the speaker may feel more capable of dealing with a topic in a language that he/she has more proficiency.

Motivation to choose one language over another cannot be separated from another professional people's advice. Communicating purely in English has been advocated by such as teachers and speech therapists when children who come from bilingual families have a delay in school (ByersHeinlein \& Lew-Williams, 2013). One participant decided to follow the advice of her children's teacher to use only English to avoid confusion. This situation is in line with the finding of ByersHeinlein and Lew-Williams in 2013 that bilingual parents feel that their child is behind other children due to their bilingualism. Therefore, they choose to speak solely in English. However, studies have dispelled this myth bilingualism does not cause language confusion, disorders and delay (Conboy, 2013; Byers-Heinlein \& Lew-Williams, 2013; Espinosa, 2015). In fact, bilinguals demonstrate some cognitive advantages over monolinguals (Bialystok et al., 2012; Blom et al., 2017). In the same manner, the experience of having difficulty gaining employment because of lack of English skills led to the participants' perception that proficiency in English would open up better opportunities and access to the major community for their children. 
Meanwhile, despite its limited use in the home, the Indonesian language was still considered to have a function as an identity mark that can connect the participants and their children to their home country and family. Even if one day, the speaker has lost the ability to speak the language, they can still selfidentify as a group member of a community (Fishman, 1965; 2001).

The children's preference to use only English at home cannot be separated from the parent's actions. Lack of persistence and encouragement from their mothers to speak in Indonesian has led the children to ignore talking in their mother's language. Moreover, the code-switching and mixing across English and Indonesian has deterred language formation. Without language separation, children will find it challenging to learn the minority language. Parents, when choosing for their children to speak in different languages, need to make sure that both languages' sources are distinct and separate, particularly in the early years of childhood when language boundaries are particularly crucial (Baker, 2000). In addition, Garcia (2000) stated that if children are not exposed to the sounds within the first six months of life, they may lose the ability to distinguish different sounds in the family. Therefore, "keeping languages separate with clear demarcation and boundaries between them will tend to make bilingual development more efficient, more socially acceptable and feed the child's language memory and language repertoire" (Baker, 2000, p. 45). When there is a lack of parental language separation in the linguistic environment, the result is language mixing in children and eventually lack of proficiency.

\section{IMPLICATIONS FOR INDONESIAN HERITAGE LANGUAGE IN CANADA}

It is a struggle to raise bilingual children, especially in a home with only one parent speaking the minority language. Without awareness of both parents about bilingualism/multilingualism and the importance of language in the home for the children's learnings and achievements, choosing a language will become more complicated. There is a note of lack of parental effort to teach the children and keep them motivated to speak the minority language. Moreover, since Indonesian language is not offered and taught in Canadian schools, Indonesian children will lose the opportunity to be educated and learn their heritage language. Another interesting finding was that professionals advised, and subsequently encouraged, the deliberate disregard for the minority language in favor of the dominant or school language. Therefore, if parents do not feel comfortable with a school teacher or speech therapist's opinion, they should seek help from other professionals with bilingual expertise.
This study found that heritage language loss among the first generation of Indonesian mixed marriage families has already occurred. Mothers bear the responsibility to transmit a specific language to their children. The mother is the first person who should introduce and later teach that language to her children. Moreover, this study confirmed that a language shift has also appeared in the participants' repertoire from Indonesian and local languages to English. Although the Indonesian language was still considered part of the participants' identity, they do not always use it.

Heritage language loss will negatively impact family relationships (Kharchenko, 2014; Kouritzin, 1999). Language shifts disturb family relationships when parents cannot teach their children moral values and enforce family rules. Kouritzin (1999) noted that when parents fail to perform their function as the family educator, they will lose power and respect from their children. As a result, family ties are shattered. Children of mixed marriages are not able to communicate with their family from Indonesia in their native language. Therefore, their connections to Indonesia, as their mother's birthplace and nationality, will cease to exist.

\section{REFERENCES}

Apfelbaum, B., \& Meyer, B. (2010). Multilingualism at work: From policies to practices in public, medical and business settings. John Benjamins Publishing Company.

Baker, C. (2000). The care and education of young bilinguals: An introduction for professionals. Multilingual Matters.

Bialystok, E., Craik, F. I., \& Luk, G. (2012). Bilingualism: Consequences for mind and brain. Trends in Cognitive Sciences, 16(4), 240-250. https://doi.org/10.1016/j.tics.2012.03.001

Byers-Heinlein, K., \& Lew-Williams, C. (2013). Bilingualism in the early years: What the science says. Learning Landscapes, 7(1), 95112. https://doi.org/10.36510/learnland.v7i1.632

Blom, E., Boerma T., Bosma, E., Cornips, L., \& Everaert, E. (2017). Cognitive advantages of bilingual children in different sociolinguistic contexts. Frontiers in Psychology, 8, 552. https://doi.org/10.3389/fpsyg.2017.00552

Berardi-Wiltshire, A. (2017). Endangered languages in the home: The role of family language in the revitalisation of indigenous languages. Revista Linguística, 13(1), 328-348. https://revistas.ufrj.br/index.php/rl/article/view File/10434/7926

Canagarajah, S. (2008). Language shift and the family: Questions from the Sri Lankan Tamil diaspora. Journal of Sociolinguistics, 12(2), 1- 
34. https://doi.org/10.1111/j.1467-

9841.2008.00361.x

Campbell, L., Lee, N. Y., Okura, E., Simpson, S., \& Ueki, K. (Eds.). (2013). Proceedings of the 3rd international conference on language documentation \& conservation. University of Hawaii.

Cheng, K. (2003). Language shift and language maintenance in mixed marriages: A case study of a Malaysian-Chinese family. International Journal of the Sociology of Language, 2003(161), 81-90. https://doi.org/10.1515/ijsl.2003.030

Clyne, M. (2003). Dynamics of language contact: English and immigrant languages. Cambridge University Press.

Clyne, M., \& Kipp, S. (1997). Trends and changes in home language use and shift in Australia, 1986-1996. Journal of Multilingual and Multicultural Development, 18(6), 451-473. https://doi.org/10.1080/01434639708666334

Conboy, B. (2013). Neuroscience research: How experience with one or multiple languages affects the developing brain. In B. Conboy (Ed.), California's Best Practices for Young Dual Language Learners: Research Overview Papers (pp. 1-50). California Department of Education

Cresswell, J. W., \& Plano Clark, V. L. (2011). Designing and conducting mixed methods research (2nd ed.). SAGE Publications.

Cresswell, J. W., \& Cresswell, J. D. (2018). Research design: Qualitative, quantitative, and mixed methods approaches (5th Ed). SAGE Publications.

Espinosa, L. (2015). Getting it right for young children from diverse backgrounds: Applying research to improve practice $\left(2^{\text {nd }} \mathrm{Ed}\right)$. Pearson.

Eberhard, E., David, M., Simons, G. F., \& Fennig, C. D. (2020). Ethnologue: Languages of the world. SIL International.

Fishman, J. A. (2001). Can threatened languages be saved: Reversing language shift, revisited. Channel View Publications.

Fishman, J. A. (1965). Who speaks what language to whom and when? La Linguistique, 1(2), 6788.

Fishman, J. A. (2013). Language maintenance and language shift as a field of inquiry: A definition of the field and suggestions for its further development. Linguistics, 51(Jubilee), 9-10. https://doi.org/10.1515/ling-2013-0038

Fishman, J. A. (1991). Reversing language shift: Theoretical and empirical foundations of assistance to threatened languages. Multilingual Matters.

Giles, H., Bourhis, R. Y., \& Taylor, D. M. (1977). Towards a theory of language in ethnic group relations. Academic Press.

Grosjean, F. (1982). Life with two languages: An introduction to bilingualism. Harvard University Press.

Holmes, J. (2013). An introduction to sociolinguistics (4th ed). Pearson.

Igboanusi, H., \& Wolf, H. (2009). The role of ethnically mixed marriages in language shift: A case study of Nigeria's minority languages. Sociolinguistic Studies, 3(3), 451-64. https://doi.org/10.1558/sols.v3i3.451

Kharchenko, N. (2014). Heritage language maintenance or loss: A difficult choice for immigrant parents. University of Manitoba.

Kouritzin, S. G. (1999). Facets of first language loss. Lawrence Erlbaum Associates, Publishers.

Li, G. (2006). Biliteracy and trilingual practices in the home context: Case studies of ChineseCanadian children. Journal of Early Childhood Literacy, 6(3), 355-381. https://doi.org/10.1177/1468798406069797

Moyer, D. (2017). Indonesian Canadians. The Canadian Encyclopedia. https://www.thecanadianencyclopedia.ca/en/art icle/indonesians

Patton, M. Q. (2015). Qualitative research \& evaluation methods: Integrating theory and practice (4th Ed). SAGE Publications, Inc.

Pauwels, A. (2005). Maintaining the community language in Australia: Challenges and roles for families. International Journal of Bilingual Education and Bilingualism, 8(2), 124-131. https://doi.org/10.1080/13670050508668601

Pauwels, A. (2016). Language maintenance and shift. Cambridge University Press.

Pendakur, R. (1990). Speaking in tongues: Heritage language maintenance and transfer in Canada. Multiculturism and Citizenship Canada, 1-119.

Piller, I. (2009). "I always wanted to marry a cowboy": Bilingual couples, language, and desire. In T. A. Karis \& K. D. Killian (Eds.), Intercultural Couples: Exploring Diversity in Intimate Relationships (pp. 3-20). Routledge.

Romaine, S. (2017). Multilingualism. In M. Aronoff \& J. Rees-Miller (Eds.), The handbook of linguistics (pp. 541-556). John Wiley \& Sons, Ltd.

Rosenblatt, P. C. (2009). A systems theory analysis of intercultural couple relationships. In T. A. Karis \& K. D. Killian (Eds.), Intercultural couples: Exploring diversity in intimate relationships (pp. 3-20). Routledge.

Skutnabb-Kangas, T. (1981). Bilingualism or not: The education of minorities. Multilingual Matters.

Skutnabb-Kangas, T. (2013). Linguistic genocide in education or worldwide diversity and human rights? Routledge.

Schwartz, M. (2008). Exploring the relationship between family language policy and heritage language knowledge among second generation 
Russian-Jewish immigrants in Israel. Journal Multilingual Multicultural Development, 29, 400-418. https://doi.org/10.1080/01434630802147916

Smith-Christmas, C. (2015). Family language policy: Maintaining an endangered language in the home. Springer.

Statistics Canada. (2018). Mixed union in Canada. Statistics Canada.

https://www12.statcan.gc.ca/nhs-enm/2011/assa/99-010-x/99-010-x2011003_3-eng.cfm

Tse, L. (2001). Heritage language literacy: A study of U.S. biliterates. Language, Culture and Curriculum, 14(3), 256-268.

https://doi.org/10.1080/07908310108666627
Tawalbeh, A. (2019). Theoretical approaches and frameworks to language maintenance and shift research: A critical review. Apples: Journal of Applied Language Studies, 13(2), 23-44. https://doi.org/10.17011/apples/urn.201903051 738

Tandefelt, M. (1992). Some linguistic consequences of the shift from Swedish to Finnish in Finland. In W. Fase, K. Jaspaert \& S. Kroon (Eds.), Maintenance and Loss of Minority Languages (pp. 54-66). John Benjamins Publishing Company.

Wei, L. (2000). The bilingualism reader. Routledge.

\footnotetext{
i According to the Employment Equity Act, visible minority refers to a person, other than Aboriginal, who are nonCaucasian in race or non-white in colour. The visible minority groups include South Asian, Chinese, Black, Filipino, Latin American, Arab, Southeast Asian, West Asian, Korean, Japanese (Canadian the Minister of Justice, 2017)
} 